\title{
TURKEY'S ELECTRICITY MARKET CURRENT SITUATION AND ALTERNATIVE POLICY RECOMMENDATIONS*
}

\section{Türkiye Elektrik Enerjisi Piyasasında Mevcut Durum ve Alternatif Politika Önerileri}

\section{İlknur Yeșim DİNÇEL}

\begin{abstract}
Keywords:

Electricity Power

Market,

Regulation,

Privatization

JEL Codes:

Q2, Q31, Q41

While electricity markets were in a vertically integrated structure in many countries, it became one of the sectors where neo-liberalization was reflected after 1980. Privatizations aimed to transform the electricity market into a competitive structure. In this study, the stages of the breaking of the monopoly structure in the Turkish electricity market and the gradual reduction of the public's share in the market were discussed. The process is described and based on official data and statistics on the recent situation reached by the electricity sector. The findings reveal that expectations did not meet as a result of privatization in the Turkish electricity market. The increases in retail electricity prices, the excess amount of spare power that is idle due to the excess supply, the production with imported resources when there is the possibility of using domestic resources, and the high share of energy imports in the foreign trade deficit naturally indicate that the expected output as a result of privatization has not been achieved. It reveals that the package of energy policies that take care of resource efficiency and efficiency should be implemented in a short time and long term in domestic electricity production, which is far from rational.
\end{abstract}

\author{
Anahtar Kelimeler: \\ Elektrik Enerjisi \\ Piyasas1, \\ Regülasyon, \\ Özelleştirme
}

JEL Kodları:

Q2, Q31, Q41
Öz

Elektrik enerjisi piyasaları birçok ülkede dikey bütünleşik yapı halindeyken, 1980 yılı sonrasında neo-liberalleşmenin yansıdığı sektörlerden olmuștur. Özelleştirmeler ve reformlar ile elektrik enerjisi piyasasının rekabetçi bir yapıya dönüştürülmesi amaçlanmıştır. Bu çalışmada Türkiye elektrik enerjisi piyasasındaki monopol yapının kırılma aşamaları ve kamunun piyasadaki payının kademeli olarak azalma süreci ele alınmıştır. Süreç ayrıntıları ve elektrik enerjisi sektörünün ulaştığı son durum resmî veri ve istatistiklere dayanılarak anlatılmıştır. Elde edilen bulgular, Türkiye elektrik enerjisi piyasasında özelleştirmeler sonucunda beklentilerin karşılık bulamadığını ortaya koymaktadır. Perakende elektrik fiyatlarındaki artışlar, oluşan arz fazlalığı nedeniyle atıl bekleyen yedek güç miktarının fazla oluşu, yerli kaynak kullanılma imkanı varken ithal kaynaklar ile üretim yapılması ve doğal olarak dış ticaret açığındaki enerji ithalatının payının yüksek oluşu özelleştirmeler sonucu oluşması beklenen çıktılara ulaşılamadığını göstermektedir. Rasyonellikten uzak olarak yapılan yurtiçi elektrik üretiminde kısa sürede ve uzun vadeli olarak kaynak etkinliği ve verimliliği gözeten enerji politikaları paketinin uygulamaya alınması gerekliliği görülmektedir. Bu bağlamda çeşitli politika önerileri geliştirilmiştir.

\footnotetext{
* This study is derived from the master's thesis that Marmara University Institute of Social Sciences Department of Economics "Competition-Capitalist Regulatory Requirements and Applications in Turkey after 1990: The Case of Electricity Market".

${ }^{* *}$ Res. Asst., Harran University, Department of Economics, dincelyesim@ harran.edu.tr, ORCID: 00000001-6367-7949
}

Makale Geliş Tarihi (Received Date): 07.10.2020 ～Makale Kabul Tarihi (Accepted Date): 31.03.2021 


\section{Introduction}

The 1970-1980 period, which is accepted as one of the transition periods in the history of the economy, draws attention as the period in which the free market economy gained importance by leaving the state model that assumed an interventionist role with the understanding of the social state. In this period, the role of the state was limited to making regulations aimed at protecting competition in the market, and ensuring their monitoring. In the 1980s, the opposition to intervention with the neo-liberalization process became more evident. In the neo-liberalization process, Britain and the United States of America started deregulation and privatization activities to add a new dimension to the state-market relations (Chang, 1997, p. 712).

Depending on their dynamics, different regulations are applied in the markets. While there is less need for regulations in a competitive market, the need for regulations is increasing to prevent abuse of the dominant position in the monopoly market. Besides, in vertically integrated markets, if the dominant firm operates in sub-markets, regulations are needed against the possibility of abuse of the dominant position. The regulation to be made in the electricity energy sector, which is the area of study of this study, also depends on the structure of the market (Akçollu, 2003, p. 20).

While electricity energy markets are in a vertically integrated structure in many countries, they are among the sectors where neo-liberalization reflected after 1980. Privatizations and reforms aimed to transition from a natural monopoly to a competitive structure in the electricity market. In this study, the process of transformation and privatization process of electricity in Turkey took place in the monopoly market structure is discussed. Besides, the latest situation of the electricity energy sector was evaluated in the light of official data.

The capacity of a firm to produce at a level to meet all demand in the market shows that that market is a natural monopoly market. In these markets, the state generally attaches importance to the protection of the natural monopoly state and restricts the entry into the market, since the resource allocation and cost-effectiveness occur when it is left to the private sector and requires serious infrastructure such as telecommunication, railway, electricity, natural gas, and not all consumers can benefit from these services. Thus, with the economy of scale, the supply of a single producer at low cost and the access of large masses to this supply is provided.

Despite the monopoly production right is given to a company or a group by the state, state control, and regulations are also required in these markets against possible abuse that may arise. When looking at the electricity energy markets, two types of regulations are encountered, namely technologic regulations and economic regulations (Zenginobuz, 2000, p. 113). Technical regulations are the development of standards regarding engineering and operational affairs, safety and technology at the production, transmission, and distribution stages and the supervision of the market by the regulatory authority. Technical issues related to electricity generation and delivery or rules and restrictions regarding environmental pollution are determined and these are open to inspection, constituting an example for technical regulations. Economic regulations, on the other hand, are the regulation of prices directly or indirectly in case of imperfect competition.

The regulations seen in the three basic units that make up the structure of the electricity energy market are made as follows: There is a need for technical regulations in the production 
phase, the necessity of economic regulations depends on the structure of competition at this stage. Turkey in the formation stage of the transmission of natural monopolies in the transport and processing of the rest of the system healthy and competitive environment is needed in terms of the technical regulations. From this point of view, economic regulations are necessary as well as technical regulations at the transmission stage. While economic regulations are predominant in the distribution stage, technical regulations are needed for the delivery of electricity to consumers in a safe and standard way when looking at the retail sales stage (Zenginobuz, 2000, p. 113-114).

Turkey on 24 January 1980 Decisions adopted by starting with the neo-liberal policies of import substitution process from the industry open to foreign models, has passed the competitive market model, it has begun to reduce the state's share in the economy. Besides, the increased costs due to the Oil Crisis have been reflected in the public-owned electricity market, and serious problems have occurred in the public sector regarding the transfer of resources to the sector. In this case, the electricity market was also reflected in Turkey and electricity monopolies were privatized market economy is gradually Authority. As stated in the Electricity Energy Sector Reform and Privatization Strategy Document, privatizations can prevent the lack of resources in the public sector, get out of the public sector's role as an operator, provide electricity in an adequate and quality manner, open the sector to competition, reduce technical losses, and prevent illegal electricity use and comply with the European Union Acquis is intended to be provided. With the Build Operate Transfer (BOT), Build and Operate (BO), and operating right transfer models, the private sector's entry into the sector has started. To ensure market control and management, it has been left to the Energy Market Regulatory Authority (EMRA), an independent regulatory body authorized to supervise the provision of electricity energy at high quality, safe and reasonable prices, to supervise its establishment in a way that does not create negative externalities for the environment, and to make the necessary regulations.

Governments could not completely give up their control over the energy market since the full liberalization of the energy market will affect many social groups and strategic issues such as energy supply security, and this situation has been an important obstacle in realizing the competition principles that the institution is intended to apply. For this reason, the energy market has been a sector that has been tried to be shaped by more than one authority such as EMRA, ministry, and government. ${ }^{1}$

\section{Historical Background and Sector Development in Turkey}

The hydroelectric power plant, which was established in Tarsus in 1902 and operated with a water mill, and the first electricity generation during the Ottoman Empire period, was followed by the coal-powered Silahtarağa Power Plant, which was established by the Hungarian company on the shores of the Golden Horn in 1914 and brought from Zonguldak. Certain sections of Istanbul until 1952 to provide electricity alone Silahtarağa Power Plant, Turkey has been producing and distributing a wide range of electricity power plants first. After 1952, the

${ }^{1}$ Ethics of research and publication were followed in this study, which does not require permission from the ethics committee. 
Ambarlı Power Plant and the Silahtarağa Power Plant, which met the electricity needs of Istanbul, were closed in 1983 (Engin, 2010, p. 243).

Turkey in the first institutionalization in the electricity market has been through in Turkey Electricity Authority Act No.1312 in 1970. More efficient use of electricity First Five Year Development Plan produced, electricity work of managing one hand and reach a larger segment of the population to have been expressed that the establishment of Turkey Institution economy. Turkey Electricity Authority was established by law as a state economic entities and electricity production under the monopoly is held responsible for the transmission and distribution. A vertically integrated structure is formed through Turkey Electricity Authority in the electricity market.

In 1973, with the Oil Crisis, costs increased in the world economy, and privatization and neo-liberalization started to gain importance in the electricity sector, which is under public ownership (Ünal, 2007, p. 84). This situation is also reflected in Turkey. 1980 Turkey of the internal market, neo-liberalization of international trade and finance has witnessed a large extent. In this new market-oriented regime, privatization was seen as a tool to overcome the inefficiencies common in the public sector. Besides, privatization is a strong reason for public finances in the 1990s is a high public deficit and debt woes in Turkey. With the voluminous increase in electricity demand, Turkish governments tried to reduce the burden on the public budget by attracting private sector investors to the electricity sector for the investments required to increase production capacity (Atiyas, Çetin and Gülen, 2012, p. 21).

Law No. 2705 in 1982, and Turkey Electricity Authority's monopoly in electricity generation, transmission, and distribution, electricity generation by opening the front of making the private sector the market entry of private enterprises is provided. Law No. 3096 in 1984 with the production of electricity for domestic and foreign private companies outside, transmission, distribution and trade has been liberalized. The supply monopoly in the electricity market has begun to be stretched and the establishment of a competitive structure. In 1994, Turkey Electricity Authority more effectively and efficiently in line with employment and privatization policies, Turkey Electricity Generation-Transmission Corporation (TEAŞ) and Turkey Electricity Distribution Company (TEDAŞ) under the name of two separate economic states enterprises.

As an alternative to intensifying private sector activities in the electricity market and as an alternative to the lack of public sector resources; BOT, BO and operating rights transfer practices started in 1994, 1996, 1997 and 1999 (Çetintaş and Bicil, 2015, p. 10). An important common feature of these agreements; the buyer purchases a certain amount of electricity at predetermining prices or agreements that commit to purchasing for 15-30 years (Atiyas et al., 2012, p. 22). The BOT model is a kind of financing method for public investments (Zenginobuz, 2000, p. 120) According to the BOT, private companies can establish the power plant through public tenders and transfer it to the public after a certain period. During the operation, the public undertakes to purchase the amount of electricity determined by the contract at the determining prices. According to the $\mathrm{BO}$ model, investors establish and operate thermal power plants through public tenders. With the agreements signed at the beginning, it is guaranteed that the public will buy a certain amount of energy at determining prices (Zenginobuz, 2000, p. 120). Transfer of operating rights is the transfer of electricity energy generation, transmission, distribution and trade activities for a certain region to the company through a public tender for a 
certain period. In the transfer of operating rights, the company that receives the tender is given a price and purchase guarantee (Zenginobuz, 2000, p. 120).

However, these agreements also brought about discussions (Atiyas et al., 2012, p. 22). For example; some contracts, especially some BOT contracts awarded by Law No. 3996, were awarded based on offers collected from pre-selected companies without a competitive procedure. These contracts do not provide a framework for competition in the market; contracts are subject to competitive offers (Çakarel and House, 2004, p. 6). Second, the tariffs in the contracts are heavily front-loaded to allow the early collection of costs. Therefore, electricity purchased by the state was expensive, especially in the first years of contracts. It was also thought that the state did not negotiate adequately on contracts and that weak bargaining was exhibited.

By the year 2001, the electricity market in the shift to free competitive market and TEAŞ transmission, to differentiate between Turkey Electricity Transmission Company production and trade activities (TEİAŞ), Electricity Generation Inc. (EGC) and Turkey Electricity Trading and Contracting Co. (TETAŞ), divided into three separate economic state enterprises.

In 2001, with the Electricity Market Law No. 4628, the necessary infrastructure was prepared for a market that is open to competition and domestic and foreign investors are at the forefront with the regulation for the production, transmission, distribution and presentation of electricity energy to ensure that the activities in the electricity energy market are carried out effectively. TEAŞ, as the sole authority of electricity transmission with the term licenses required for generation and distribution to domestic and foreign companies that want to operate in the market, has been enacted by law. With the law, it is aimed to continue production and sales activities from the market vertically integrated structure in a competitive environment and to transform the distribution and transmission activities, which are natural monopolies, into a market environment where they are regulated. Besides, EMRA was established with the Electricity Market Law No. 4628; has been held responsible for market monitoring, license distribution, determination and inspection of pricing principles.

Electricity market of electricity production in Turkey, transmission through the energy received from the manufacturer's high-voltage transmission lines, energy and electricity supply to the retail market high or low voltage output as the transmission via the regional distribution network is based on three units as transmission and distribution (Çakal, 1996, p. 79-80).

Turkey Electricity Authority is a state monopoly under the electricity market, which operates as a single structure, from transmission production in 1994 (high voltage) from TEAŞ and distribution as responsible (low voltage) is divided into two priorities as TEDAŞ responsible. In 2001, TEAŞ; It was restructured as Turkey Electricity Production Co. (EÜAŞ), TEİAŞ, and TETAŞ. This process is shown in Figure 1.

Figure 1 shows, Turkey Electricity Authority is divided into two branches primarily responsible for TEDAŞ with TEAŞ responsible for the distribution and transmission production. Subsequently, TEAŞ was divided into three sub-institutions as EÜAŞ, TEİAŞ, and TETAŞ, where generation, transmission, and wholesale are carried out separately. At the same time, TEDAŞ divided its electricity distribution business into 21 local regions and transferred it to separate distributors for each region. 


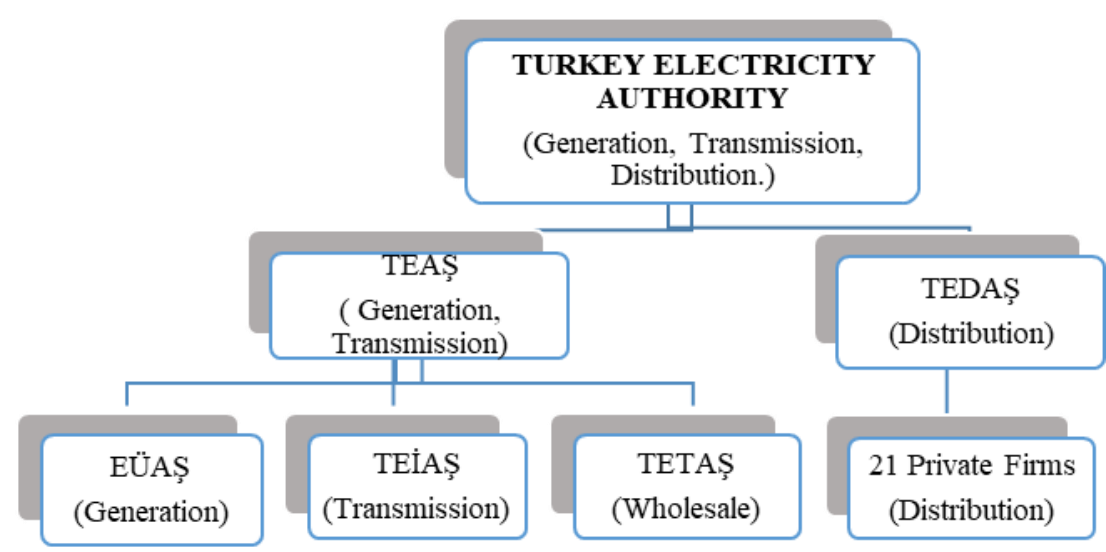

Figure 1. Transformation in the Turkish Electricity Market

Source: World Bank (2015), Turkey’s Energy Transition Milestones and Challenges, July 2015.

In 2001, with the Electricity Market Law No. 4628, the transition to a competitive structure was initiated by licenses granted to domestic and foreign investors in the generation and distribution phase of the electricity market, and the transmission, which was not opened to competition and continued as a natural monopoly, was kept under control by regulations (Özel, Büyüktanır and Özel, 2013, p. 2075). In the phase of electricity generation, which is open to competition, besides the public institution EÜAŞ, private investors, and auto producers operating with the transfer of BOT, BO, operating rights are operating. In 2012, with the EMRA decision dated 12/09/2012 and numbered 4019, it was decided to cancel the retail electricity sale of the companies under the distribution license and to have a separate legal entity for each activity, resulting in the creation of more sellers in the market. On the other hand, companies with distribution licenses provide the energy they provide from the transmission facilities established and operated by TEIAŞ as a natural monopoly due to the high additional costs associated with the establishment of separate transmission facilities in the regions specified in their distribution licenses. TEDAŞ, on the other hand, was divided into 21 local distributors, and with the privatization of the last distribution company in 2013, the electricity distribution activity was completely transferred to the private sector (Özdemir, 2014). As can be seen, while there is competition in the generation and distribution side of electricity energy, TEİAŞ operates as a natural monopoly in the transmission stage.

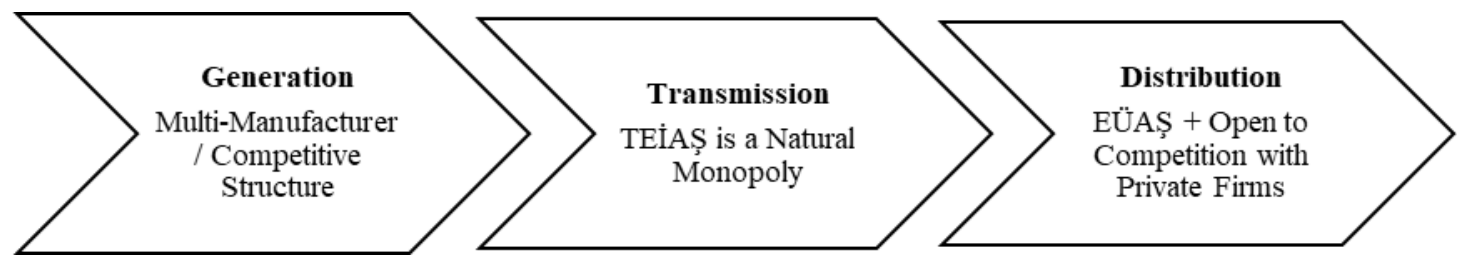

Figure 2. Competition in the Electricity Energy Market

The electricity market liberalization process of Turkey is summarized in Table 1 . As can be seen, with the establishment of EMRA in 2001, the process of reducing public ownership in 
the electricity sector started and the private sector's entry into the market has continued until today.

Table 1. Turkey Electricity Market Liberalization Process

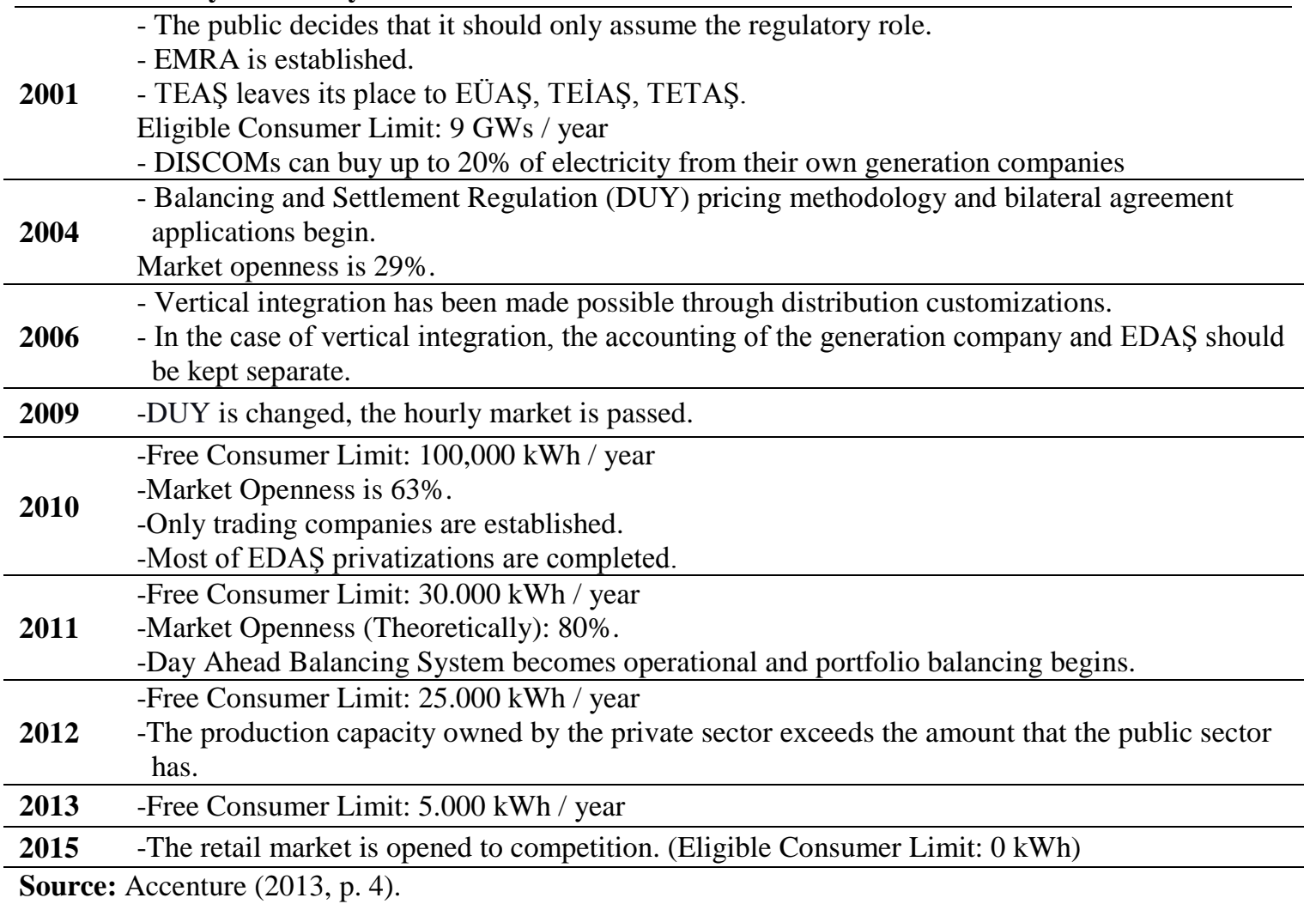

\section{Analysis of Current Situation}

Turkey electricity market in Turkey and then in the process of allocating the Electricity Authority to grant up to 21 regional distributors of electricity distribution monopoly; installed power, type, and origin of energy used in electricity generation, change in energy imports, loss and leakage rates and many factors are important in terms of market and energy policies. The current status of Turkey's electricity market can be demonstrated by a variety of data.

Figure 3 shows, the installed power of the facilities established for electricity generation in 1972 is presented. In the light of the data obtained from TEİAŞ installed capacity of power plants in Turkey but overall uptrend show won together in 2011 after growth and installed capacity increased by 49\% compared to the previous year in 201785200.0 reached Megawatts. In 2019, the total installed power was 91.267,00 Megawatt. 


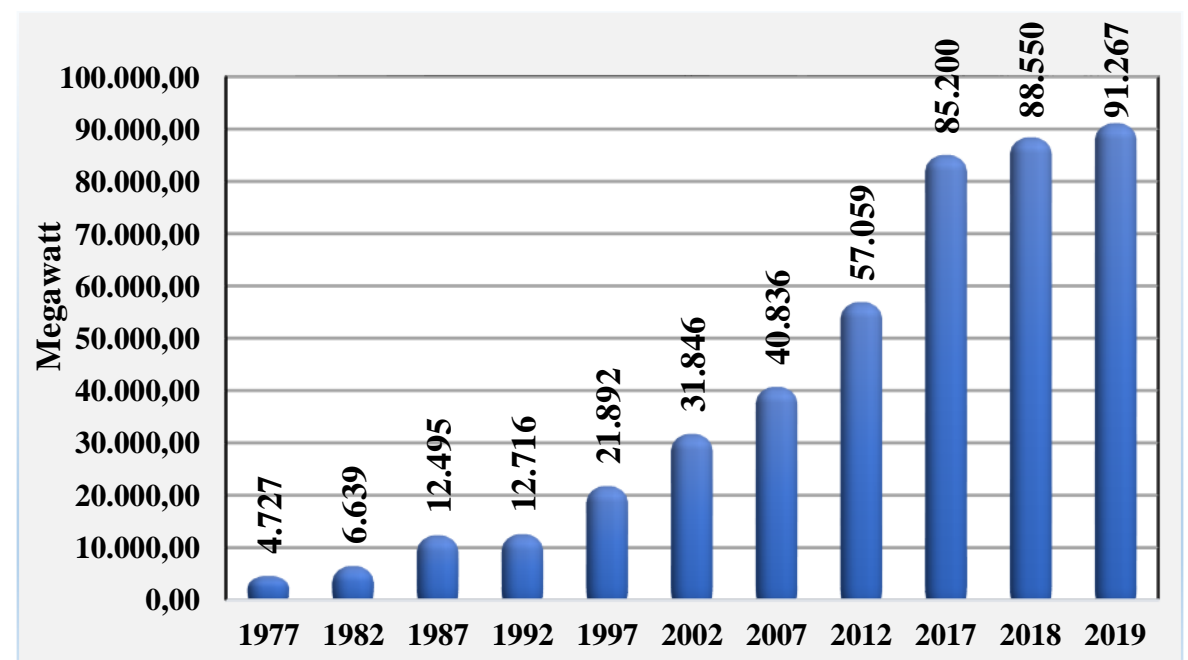

Figure 3. Change of Annual Installed Capacity in Turkey Source: TEİAŞ

Figure 4 shows, the share of public and private sectors in installed power as of 2007. Neo-liberalization in energy markets started in many countries in the early 1990s and energy markets started to form with legal regulations. Turkey has started the process with the reflection of the Electricity Authority's establishment, after TEDAŞ, has continued with EGC and TEAŞ. The share of the public in the electricity sector has decreased to $21.5 \%$ in 2019 . According to the International Energy Agency (IEA), after the completion of the privatization process, the share of the private sector is estimated to reach at least $90 \%$ of the total installed power. It is planned to privatize all public thermal power plants and some hydroelectric power plants ( 8 thermal power plants and 49 hydroelectric power plants with a total capacity of $12 \mathrm{GW}$ ). Thermal power plants of Seyitömer, Kangal, Hamitabat, Yatağan, Yeniköy and Kemerköy were privatized in 2013 and 2014, and Çatalağzı, Soma, Orhaneli and Tunçbilek thermal power plants as of January 2015.

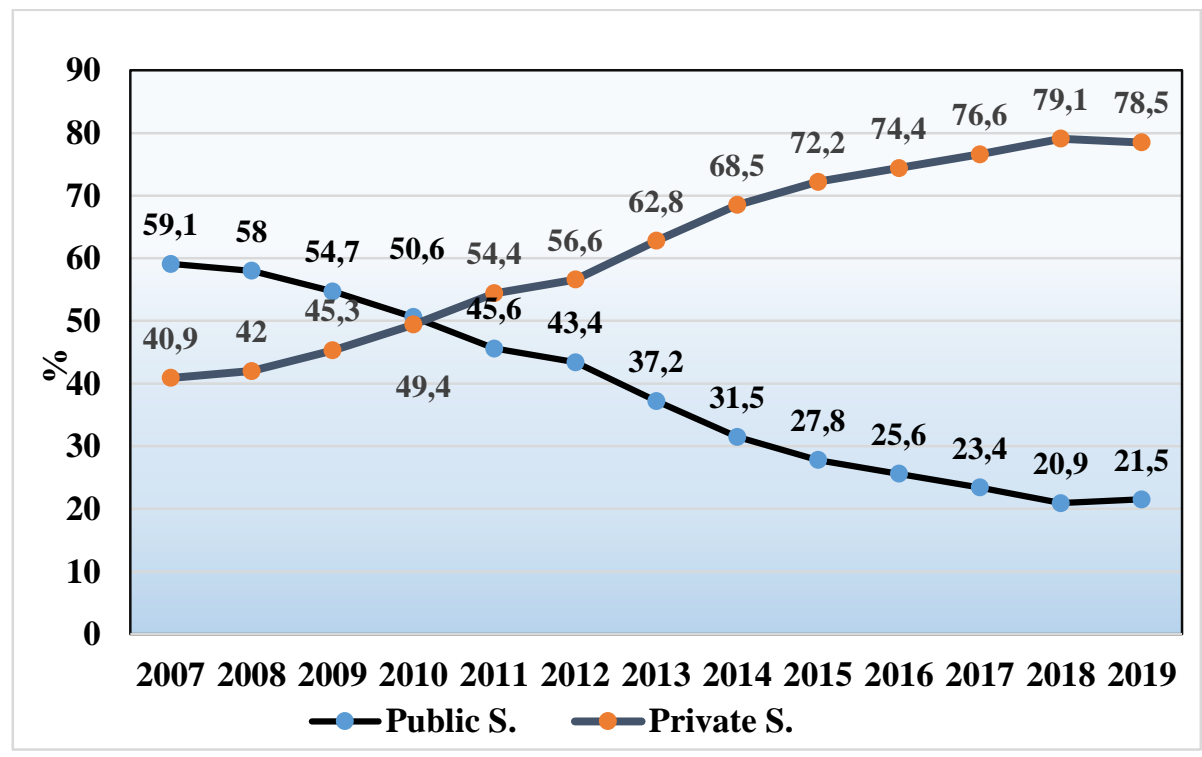

Figure 4. Distribution of of Installed Capacity in Public and Private Sector in Turkey Source: TEİAŞ 
Figure 5 shows, installed capacity in Turkey was given the 2009-2019 year according to changes in the distribution of primary energy sources. Approximately half of the electricity produced in 2019 was produced in thermal power plants that produce from fossil fuels such as natural gas and coal. Although production from renewable sources such as wind, solar and geothermal has come to the fore in recent years, predominant production continues through fossil fuels. At this point, foreign dependence on fossil fuels and energy comes to the fore. While 43.604,0 Megawatts of the total 91.267,0 Megawatts of energy produced in 2019 consisted of renewable resources, 47.663,0 Megawatts of it was obtained from non-renewable sources such as hard coal, lignite, liquid fuel.

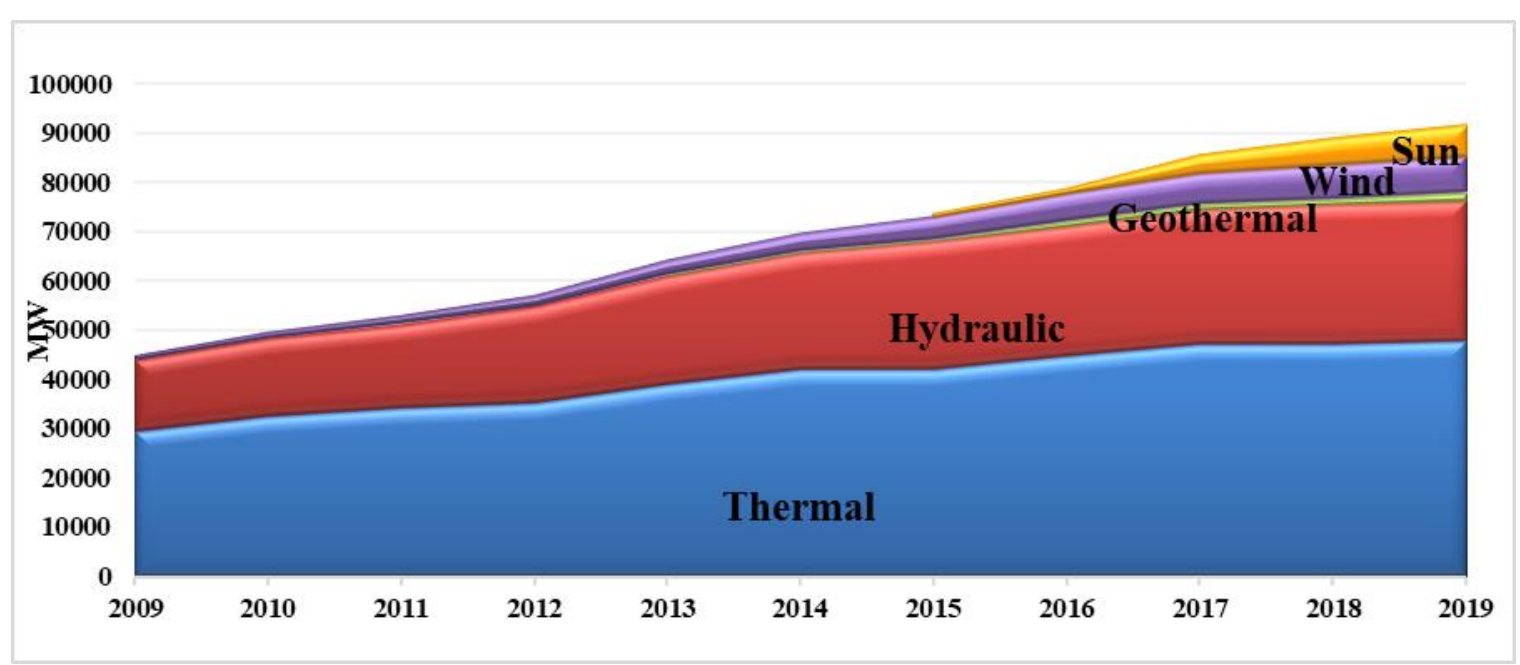

Figure 5. Distribution of Primary Energy Sources at Installed Power in Turkey (2009-2019) Source: TEİAŞ

In 2009, the highest production based on energy resources was obtained from thermal power plants operated with coal, natural gas, and other fuels, which are fossil fuels, with $29.339,0$ megawatts. This production amount corresponds to approximately $65.5 \%$ of the total production. Power plants made of hydroelectric, which is a renewable energy source with 15.422,0 megawatts, are followed by the ranking. While the production from sun, win, and geothermal resources has increased dramatically in 10 years. Besides, electricity generation from fossil fuels has decreased total. Turkey, the IEA to be the best penetration rate of renewable electricity member located between countries.

Looking at Figure 6, the sources of electricity energy generation in 2019 can be seen. It is noteworthy that electricity generation is predominantly made from fossil fuels. Turkey solar, wind, and geothermal, including, have a high potential for renewable energy sources. $48.64 \%$ of the energy obtained from renewable energy sources is obtained from biomass and animal waste, while the remaining part is obtained from hydraulic, solar, wind and geothermal energy. By using renewable energy sources, it is possible to reduce the rate of imported fossil fuels and to reduce the damage to the environment with renewable energy. Despite this, the production made with fossil resources is much more intense. 


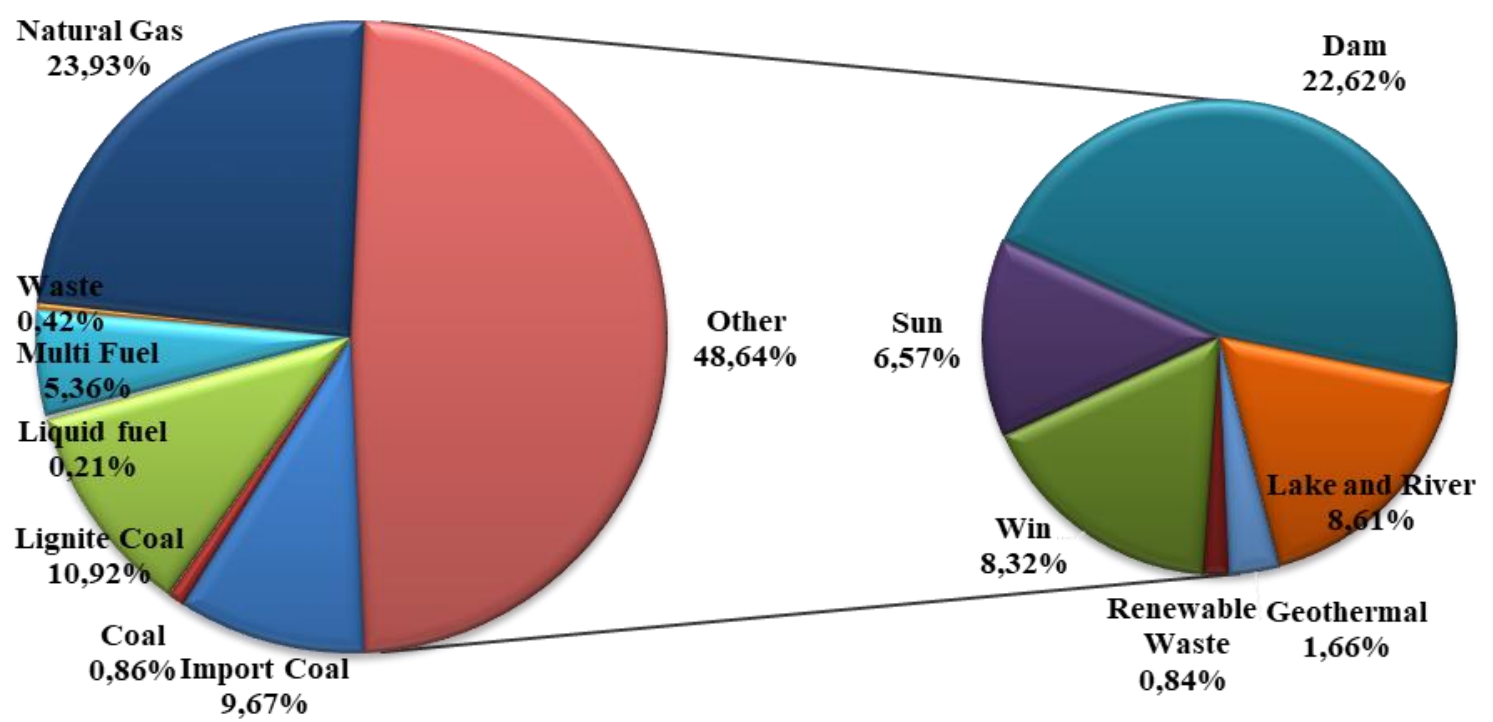

Figure 6. Distribution by Sources of Electricity Energy Production in Turkey, 2019.

Source: TEİAŞ

Figure 7 shows, the share of domestic and imported resources in the installed power between 2000-2019. Despite periodic decreases, the ratio of imported resources constitutes more than half of the total resources. In 2019, the ratio of imported resources was $61.5 \%$. Despite Turkey's indigenous coal and renewable energy sources, at this point, it exhibits poor performance in self-reliance. More than half of the energy needs, almost all oil and natural gas demand, are imported, and this energy import significantly increases the foreign trade deficit.

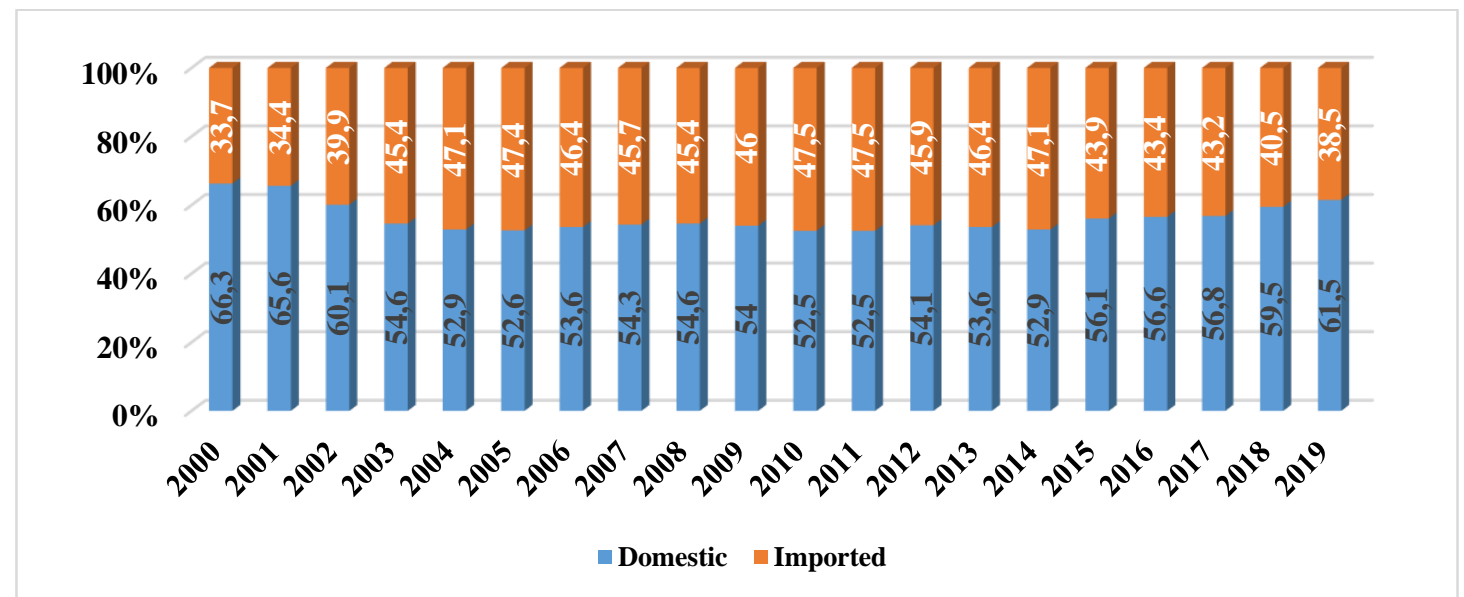

Figure 7. Ratio of Domestic and Imported Resources in Installed Capacity Between 2000-2019 Source: TEIAȘ

* The installed power of multi-fuel power plants is not included.

Figure 8 show, peak power demand values between the years of 1985 to 2019 in Turkey's electricity market. Peak power demand is a technical concept and it refers to the amount of electrical energy that is measured in watts and can be instantly produced by a power plant at times when demand is at its highest. The importance of this value can be understood as follows. 
The difference between the amount of installed power and peak power given in the previous figures is a serious waste of resources. For example, in 2019, the peak power demand was 45.324.0 Gigawatts, while the installed power in 2019 was 91.267 Megawatts. There is about 2 times the supply of demand. This situation is a serious waste of resources and a wrong planning indicator for a developing country such as Turkey.

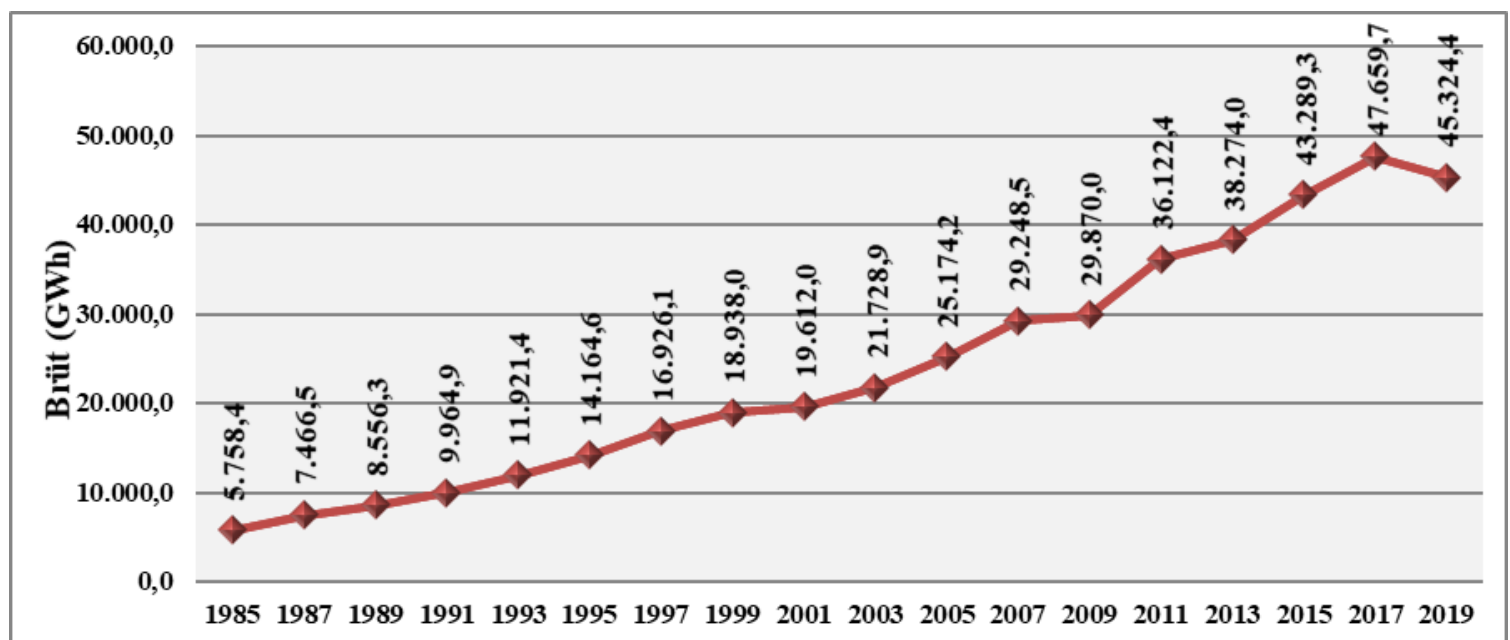

Figure 8. 1985-2019 Peak Demand in Turkey Electricity Market Source: TEİAŞ

Table 2 shows, the ratio of import, foreign trade deficit, energy imports and energy imports to the foreign trade deficit for the years 2009-2019. When the data are analyzed, it is observed that total imports follow an increasing trend. However; Although the foreign trade deficit decreased relatively in 2014, 2015 and 2016, the general trend was in the direction of increase. Although energy imports are mostly on a declining course, the foreign trade deficit has reflected on energy imports at a decreasing rate and even though the decrease in energy imports in 2014, its effect on the foreign trade deficit has increased. Foreign dependency on energy clearly shows itself in the foreign trade deficit.

Table 2. Ratio of Energy Imports in the Foreign Trade Deficit Between 2009-2019

\begin{tabular}{lcccc}
\hline Year & $\begin{array}{c}\text { Total Import } \\
\text { (BillionUSD) }\end{array}$ & $\begin{array}{c}\text { Foreign Trade } \\
\text { Balance } \\
\text { (BillionUSD) }\end{array}$ & $\begin{array}{c}\text { Energy Import } \\
\text { (BillionUSD) }\end{array}$ & $\begin{array}{c}\text { The Ratio of Energy Imports } \\
\text { to Foreign Trade Balance (\%) }\end{array}$ \\
\hline $\mathbf{2 0 0 9}$ & 140,92 & $-12,16$ & 29,90 & 245,88 \\
$\mathbf{2 0 1 0}$ & 185,54 & $-45,47$ & 38,49 & 84,64 \\
$\mathbf{2 0 1 1}$ & 240,84 & $-75,09$ & 54,11 & 72,06 \\
$\mathbf{2 0 1 2}$ & 236,5 & $-84,1$ & 60,1 & 71,46 \\
$\mathbf{2 0 1 3}$ & 251,7 & $-99,9$ & 55,9 & 56 \\
$\mathbf{2 0 1 4}$ & 242,2 & $-84,6$ & 54,9 & 64,8 \\
$\mathbf{2 0 1 5}$ & 207,1 & $-63,1$ & 37,8 & 59,90 \\
$\mathbf{2 0 1 6}$ & 198,6 & $-56,1$ & 27,2 & 48,5 \\
$\mathbf{2 0 1 7}$ & 233,8 & $-76,8$ & 37,2 & 48,4 \\
$\mathbf{2 0 1 8}$ & 236 & -66 & 46 & 69,6 \\
$\mathbf{2 0 1 9}$ & 253 & -71 & 45 & 63,38 \\
\hline Source: Ministry of Development (2013, 2015, 2018, 2019) (Medium Term Program 2019-2021), \\
(Medium Term Program 2018-2020), (Medium Term Program 2015-2017), Tenth Development Plan \\
(2014-2018)
\end{tabular}


After the privatizations, international capital inflows were experienced in the electricity market, and companies with foreign capital started to operate in the market. Table 3 shows, companies with foreign capital operating through auctions in 21 distributor regions and their shares in the company capital are listed. The weight of German and Dutch companies in the electricity market is remarkable.

Table 3. Companies with Foreign Capital in the Electricity Market

\begin{tabular}{|c|c|c|}
\hline Firms & Location & Origin \\
\hline Afyon Enerji ve Gübre Üretim Ticaret ve Sanayi A.Ş. & Afyon & Germany $(\% 5)$ \\
\hline Ak Gıda Sanayi ve Ticareti A.Ş. Pamukova & Sakarya & Belgium $(\% 80)$ \\
\hline Amylum Nişasta Sanayi ve Ticaret A.Ş. & Adana & Netherlands (\%100) \\
\hline Baymina Enerji A.Ş. & Ankara & Netherlands (\%95) \\
\hline Cev Marmara Enerji Üretim San. ve Tic. Ltd. Şti. Bolu & Bolu & S. Korea $(\% 100)$ \\
\hline Ege Profil Tic. ve San. A.Ş. & İzmir & Belgium $(\% 95,88)$ \\
\hline EnerjiSa Enerji Üretim A.Ş. Bandırma 2 & Balıkesir & Germany $(49,99)$ \\
\hline EnerjiSa Enerji Üretim A.Ş. Hacınınoğlu & K.maraş & Germany $(49,99)$ \\
\hline EnerjiSa Enerji Üretim A.Ş. Dağdelen & K.maraş & Germany $(49,99)$ \\
\hline EnerjiSa Enerji Üretim A.Ş. Kandil & K.maraş & Germany $(49,99)$ \\
\hline EnerjiSa Enerji Üretim A.Ş. Kavşak Bendi & Adana & Germany $(49,99)$ \\
\hline EnerjiSa Enerji Üretim A.Ş. Kozan & Adana & Germany $(49,99)$ \\
\hline EnerjiSa Enerji Üretim A.Ş. Kuşaklı & Adana & Germany $(49,99)$ \\
\hline EnerjiSa Enerji Üretim A.Ş. KentSa Santral & Kocaeli & Germany $(49,99)$ \\
\hline Frito Lay Gıda San. ve Tic. A.Ş. İzmit Fabrikası & Kocaeli & USA $(\% 100)$ \\
\hline Isparta Mensucat San. ve Tic. A.Ş. Isparta & Isparta & USA $(\% 7.5)$ \\
\hline JTI Tütün Ürünleri Sanayi A.Ş. & İzmir & Switzerland (\%100) \\
\hline Lesaffre Turquie Mayacılık Üretim ve Tic. A.Ş. Amasya & Amasya & France $(\% 100)$ \\
\hline Lesaffre Turquie Mayacılık Üretim ve Tic. A.Ş. Ceyhan & Adana & France $(\% 100)$ \\
\hline Lesaffre Turquie Mayacılık Üretim ve Tic. A.Ş. Lüleburgaz & Kirklareli & France $(\% 100)$ \\
\hline Trakya Elektrik Üretim ve Tic. A.Ş. & Tekirdağ & Russian Fd.(\%100) \\
\hline Çakıt Enerji A.Ş. Adana & Adana & Norway $(\% 100)$ \\
\hline İskenderun Enerji Üretim ve Tic. A.Ş. Adana Sugözü & Adana & Germany $(\% 51)$ \\
\hline İzmir Elektrik Üretim Ltd. Şti. & İzmir & Netherlands $(\% .02)$ \\
\hline Meltem Enerji Elektrik Üretim A.Ş. Kemalpaşa & İzmir & Netherlands (\%35) \\
\hline MMK Metalurji Sanayi Tic. ve Liman İşletmeciliği A.Ş. Dilovası & Kocaeli & Russian Fd.(\%100) \\
\hline MMK Metalurji Sanayi Tic. ve Liman İşletmeciliği A.Ş. Dilovası & Hatay & Russian Fd.(\%100) \\
\hline $\begin{array}{l}\text { PhilSa Philip Morris Sabancı Sigara ve Tütüncülük Sanayi ve } \\
\text { Ticaret A.Ș.-Torbalı }\end{array}$ & İzmir & Netherlands (\%75) \\
\hline $\begin{array}{l}\text { Reşadiye Hamzalı Elektrik Üretim Sanayi ve Ticaret A.Ş. } \\
\text { Reşadiye HES-1 }\end{array}$ & Sivas & $\begin{array}{l}\text { Czech } \quad \text { Republic } \\
(\% 100)\end{array}$ \\
\hline $\begin{array}{l}\text { Reşadiye Hamzalı Elektrik Üretim Sanayi ve Ticaret Anonim } \\
\text { Şirketi Kırıkkale }\end{array}$ & Kirıkkale & $\begin{array}{l}\text { Czech } \quad \text { Republic } \\
(\% 100)\end{array}$ \\
\hline RWE\&Turcas Güney Elektrik Üretim A.Ş. Denizli & Denizli & Germany (\%69.7) \\
\hline $\begin{array}{l}\text { Reşadiye Hamzalı Elektrik Üretim Sanayi ve Ticaret A.Ş. Aralık } \\
\text { HES Borçka }\end{array}$ & Artvin & $\begin{array}{l}\text { Czech } \quad \text { Republic } \\
(\% 100)\end{array}$ \\
\hline $\begin{array}{l}\text { Selkasan Kağıt ve Paketleme Malzemeleri İmalat Sanayi ve Tic. } \\
\text { A.Ş. }\end{array}$ & Manisa & $\begin{array}{l}\text { Netherlands } \\
(\% 82.15)\end{array}$ \\
\hline
\end{tabular}

Source: The Union of Chambers and Commodity Exchanges of Turkey (TOBB)

Table 4 shows, the illegal electricity usage rates in 21 distribution regions. Stray electricity; It is the difference between the electricity supplied to a distribution company and electricity sold. With an average of $70 \%$ over the years, the highest illegal use of electricity occurs in the region belonging to Dicle EDAŞ, which distributes to Diyarbakır, Şanlıurfa, Batman, Mardin, Siirt, and Şırnak provinces. Vangolu EDAŞ, which distributes to the provinces 
of Van, Bitlis, Muş, and Hakkari ranks second in illegal electricity usage with an average of $60 \%$. The detected illegal electricity usage methods are as follows (Köklükaya, Yıldız, Büyüktanır and Kahraman, n.d.): Reducing the rotation speed of the disk by affecting the magnetic mechanism of the measuring system on the meter with a magnetic or mechanical object, placing a different line on the line before the meter is installed, connecting the meter inputs and outputs to different lines. If the last two methods are used, it is very difficult to detect illegal electricity usage. For this reason, the exact amount of leakage electricity cannot be known.

Table 4. The Leakage Power Ratio of Activiting 21 Distributor Company in Turkey

\begin{tabular}{lcccc}
\hline Distributor & $\begin{array}{c}\mathbf{2 0 1 6} \\
\text { Target }\end{array}$ & $\begin{array}{c}\mathbf{2 0 1 6} \text { Actual } \\
\text { (EMRA) }\end{array}$ & $\begin{array}{c}\mathbf{2 0 1 7} \\
\text { Target }\end{array}$ & $\begin{array}{c}\mathbf{2 0 1 8} \\
\text { Target }\end{array}$ \\
\hline ADM EDAŞ & 7,92 & 5,74 & 7,46 & 7,15 \\
Akdeniz EDAŞ & 9,67 & 6,31 & 8,73 & 7,63 \\
AKEDAŞ & 7,46 & 7,20 & 7,07 & 7,2 \\
Aras EDAŞ & 31,68 & 25,68 & 29,37 & 25,65 \\
AYEDAŞ & 7,61 & 6,78 & 7,63 & 7,5 \\
Başkent EDAŞ & 8 & 6,98 & 7,75 & 7,64 \\
Boğaziçi EDAŞ & 9,46 & 9,61 & 8 & 7,98 \\
Çamlıbel EDAŞ & 7,96 & 5,97 & 7,82 & 7,55 \\
Çoruh EDAŞ & 9,33 & 9,25 & 9,08 & 9,02 \\
Dicle EDAŞ & 71,62 & 67,63 & 71,78 & 69,2 \\
Firat EDAŞ & 9,72 & 10,56 & 10,99 & 10,47 \\
GDZ EDAŞ & 8,47 & 7,32 & 8,31 & 7,84 \\
Kayseri ve Civarı EDAŞ & 7,45 & 5,87 & 7,17 & 7 \\
Meram EDAŞ & 7,9 & 6,65 & 7,7 & 7,66 \\
Osmangazi EDAŞ & 7,77 & 5,75 & 7,9 & 7,55 \\
Sakarya EDAŞ & 7,42 & 6,58 & 7,34 & 7,34 \\
Toroslar EDAŞ & 13,59 & 12,12 & 13,32 & 12,34 \\
Trakya EDAŞ & 7,17 & 5,46 & 7,29 & 7,12 \\
Uludağ EDAŞ & 7,54 & 5,57 & 7,47 & 7,2 \\
Vangölü EDAŞ & 60,17 & 56,42 & 60,35 & 57,27 \\
Yeșilırmak EDAŞ & 8,5 & 8,20 & 8,95 & 8,06 \\
\hline
\end{tabular}

Source: The Chamber of Electricity Engineers (EMO)

\section{Conclusion and Recommendations}

Ensuring resource diversity in electricity energy production in the 2015-2019 Strategic Plan of the Ministry of Energy and Natural Resources; was emphasized as a prominent factor inefficient use of resources and reducing risks arising from external dependency (Ministry of Energy and Natural Resources [MENR], 2015, p. 35). In this context, it is important to increase the share of renewable energy in electricity energy generation. Turkey has a very significant amount of renewable energy sources. According to statistics, in 2016 the total electricity consumed on the third floor of the new circuits in Turkey has the potential to produce even the establishment (Pamir, 2017, p. 505). According to TEİAŞ data, electricity generation with renewable energy has a share of approximately 49\% of total electricity generation in 2019 . Although increasing this ratio is important in reducing foreign dependency, there is also potential. At the same time, the exploration of domestic oil and natural gas resources and the production based on the national resources of the country will play an important role in reducing foreign dependency. 
The fact that the share of energy imports in the foreign trade deficit is around 65-70\% also reveals the need for the fastest reduction of foreign dependency on energy.

The liberalization process, which emerged as a result of the searches that started due to the insufficiency of capital accumulation and inefficiency, reduced the intervention of the state in the economic life and made international capital able to circulate without obstacles. This process has emerged as a natural consequence of privatization activities and distribution in Turkey has been a completely privatized electricity market. As a result of these auctions for distributors of foreign capital companies in Turkey has a place in the electricity market actively. The weight of foreign companies in the electricity market is increasing. The transfer of strategic sectors such as electricity from the public to the private sector is closely related to the security of the country, and it can bring many problems in terms of independence and economy (Türkoğlu, 2005, p. 139). While making arrangements, preventive measures should be taken by considering these possibilities.

The reasons for privatization in the electricity market were cited by the Privatization Administration as the creation of a more competitive market, increase in efficiency, and decrease the burden of the public in making the necessary investments. However, at this point, private enterprises avoid investment to increase their profits, energy imports are made despite the available potential resources, and therefore expensive electricity use and cuts show that what is expected from privatization is not realized.

As an example from the recent past; power outages throughout Turkey on March 31, 2015, is a network breakdown. The source of this interruption is not the distribution stage but the transmission, in other words, high voltage. This cut caused million-dollar damage to the industrial sector. According to the statement made by the Chamber of Electricity Engineers, among the reasons for the outage; Various claims were listed such as the failure of the transmission system as a result of the failure to manage the supply deficit due to the decrease in electricity prices in the market in those days, the distribution companies did not direct the available power to the system to force the government to take the loss/leakage cost (Pamir, 2017, p. 493). The fact that electricity generation, transmission and distribution work, which plays a key role in the economy of the country and the country, is undertaken by the private sector instead of the public sector has a sector structure that can feed various problems in this direction. Energy security is of great importance for the healthy functioning of the country's economies.

To prevent the situations mentioned in the example from happening again at different times, it is quite reasonable to carry out transmission, distribution and operation activities as a service by the public, and to compete over retailers during the retail sales phase (Türkoğlu, 2005, p. 141). Otherwise, due to the natural monopoly nature of electricity, the private sector will gain monopoly power in the market and the free market model and competitive environment that is tried to be provided by laws will not be created.

Another point targeted with privatizations; The competitive environment has reduced electricity prices. However, in the 15 years covering 2016, electricity supplied to residences has increased by $124 \%$ (Pamir, 2017, p. 496). When compared to OECD countries in terms of purchasing power parity; 6 . Turkey has become a country that sells the most expensive electricity (Chamber, 2018, p. 124). One of the important reasons for this expensive price; is because foreign investors reflect the risks they anticipate in the country to their investments. At 
the same time, foreign investors' demand for sales guarantees with BOT and BO models has been a factor that increased electricity prices (Türkoğlu, 2005, p. 136). In addition to providing incentives for renewable energy sources, purchase guarantees given for large-scale coal and nuclear power plants are one of the factors that will pose an obstacle to lower prices in the future (TMMOB, 2018, p. 127). Purchase guarantees given in this way should not be preferred and should be canceled as they are binding.

Besides, the exchange rate can have an increasing effect on the prices of electricity production by importing oil and natural gas. Turkey hydroelectric, wind, solar and geothermal energy has been fertile care. Despite the existing potentials, energy imports significantly disrupt the import-export balance and become an important element of the current account deficit. This situation increases energy and foreign dependency and threatens economic independence and security. With the realist perspective advocated by thinkers such as the modern state theorist Machiavelli and Thomas Hobbes, energy security will cause asymmetric dependency and the power of interest to suppress the other side (Toledo, 2005, p. 56). The steps to be taken in the use of domestic resources will both reduce dependence and reduce the use of fossil fuels that harm nature. This issue should be given special attention while shaping the energy policy.

Electricity prices are another striking point in the market is the supply-demand imbalance. Turkey Electricity Transmission Company According to the information obtained from the statistics, the electricity supply exceeded the electricity demand and idle power was created in the system. Peak load is a technical concept expressing the most demanding hours of electricity during the day. The peak load of 2019, in other words, the highest electricity demand during the year was 45,180 Megawatts (Turkey Electricity Transmission Company [TEİAŞ], 2019). The current installed power in 2019 is 91,267 Megawatts. 40,466 megawatts of energy remained idle without any use to produce approximately as much as $95 \%$ to be invested in power plants the maximum amount of electricity consumed in Turkey as a country in development is an indication of whether the resources are rationally managed.

Considering that a thermal power plant has an average economic life of 30 years, natural gas and geothermal power plants an average of 25 years, and a hydroelectric power plant an average economic life of 75 years; Closing some facilities to production even without the need for an increase in installed power will not disrupt in terms of electricity generation. Current policies need to be revised over the consumption estimates of the past years.

In Turkey, all made use of fossil energy purchase agreements and treaties must be canceled revised surplus (War Academies Command, 2006, p. 78).

All ministries and public institutions should be assigned to prioritize electricity generation using renewable energy resources, and a long-term plan should be made in line with the goal of transition to 100\% renewable energy (War Academies Command, 2006, p. 78).

Turkey was $12 \%$ loss, leakage is estimated to reach up to $70 \%$ electricity compared to the region. This rate seriously reduces the yield. Besides, the cost of lost / illegal electricity has reflected all consumers. It is also not welcome for the consumer to have the obligation to pay this price. To prevent the use of lost / illegal electricity, technical measures such as putting the electricity lines under the ground and ensuring the security of the meter, and deterrent penalties for the use of illegal electricity should be imposed. 
Strong coordination between ministries in energy research policies and financing should be ensured by encouraging the creation of research networks and consensus among R\&D institutions (International Energy Agency [IEA], 2016, p. 202).

Researcher's Contribution Rate Statement

I am a single author of this paper. My contribution is $100 \%$.

\section{Conflict of Interest Statement}

There is no potential conflict of interest in this study. 


\section{References}

Accenture. (2013). Türkiye elektrik piyasası, türkiye elektrik piyasası'nda elektrik ticareti. Retrieved from https://www.accenture.com/us-en/industries/energy-index

Akçollu, Y. (2003). Elektrik sektöründe rekabet ve regülasyon (Rekabet Kurumu, uzmanlık tezleri serisi, 117).

Atiyas, İ., Çetin, T. and Gülen, G. (2012). Reforming Turkish energy markets: Political economy, regulation and competition in the search for energy policy. New York: Springer Science.

Chang, H. (1997). The economics and politics of regulation. Cambridge Journal of Economics, 21(6), 703-728. https://doi.org/10.1093/oxfordjournals.cje.a013694

Çakal, R. (1996). Doğal tekellerde özelleştirme ve regülasyon (DPT uzmanlık tezi). Retrieved from http://www.bilgitoplumu.gov.tr/wp-content/uploads/2014/04/Recep-Cakal_Doga__Tekellerde_ Regulasyon.pdf

Çakarel, E. and House, J. (2004). IPP investment in Turkey's electric power industry (Working Paper. No. 32). Retrieved from https://fsi-live.s3.us-west-1.amazonaws.com/s3fspublic/wp32_turkish_IPPs.pdf

Çetintaş, H. and İ. Bicil. (2015). Elektrik piyasalarında yeniden yapılanma ve Türkiye elektrik piyasasında yapısal dönüşüm [Restructuring in the electricity markets and structural transformation in Turkish electricity market]. Optimum Ekonomi ve Yönetim Bilimleri Dergisi, 2(2), 1-15. Retrieved from https://dergipark.org.tr/tr/pub/optimum

Engin, N. (2010). Enerji kaynağı olarak doğalgaz ve Türkiye [The naturel gas as an energy sources and Turkey]. Marmara Coğrafya Dergisi, 22, 233-244. Retrieved from https://dergipark.org.tr/tr/pub/igge

International Energy Agency. (2016). Energy policies of IEA countries: Turkey. Retrieved from https://www.iea.org/reports/energy-policies-of-iea-countries-turkey-2016-review

Köklükaya, E., Yıldız, M., Kahraman, S. and Bayrak, M. (n.d.). Kaçak elektrik kullanımının belirlenmesi ve matlab ile benzetimi. Retrieved from https://www.emo.org.tr/ekler/b380939c45478d2_ek.pdf

Ministry of Development. (2013). Tenth development plan (2014-2016). Retrieved from https://www.sbb.gov.tr/wp-content/uploads/2018/11/Orta-Vadeli-Program_2014-2016.pdf

Ministry of Development. (2015). Medium term program 2015-2017. Retrieved from https://www.sbb.gov.tr/wp-content/uploads/2018/11/Orta-Vadeli-Program-2015-2017.pdf

Ministry of Development. (2018). Medium term program 2018-2020. Retrieved from https://www.sbb.gov.tr/wp-content/uploads/2018/11/Medium_Term_Programme_2018-2020.pdf

Ministry of Development. (2019). Medium term program 2019-2021. Retrieved from https://www.sbb.gov.tr/wp-content/uploads/2018/11/YeniEkonomiProgram\%C4\%B1_OVP_20192021.pdf

Ministry of Energy and Natural Resources. (2015). 2015-2019 stratejik plant. Retrieved from http://www.sp.gov.tr/upload/xSPRapor/files/WQD0S+enerji_gov_tr_File_path_ROOT_1_Docum ents_Mali_Tablo_Performans_Programi_2015.pdf

Özdemir, B. (2014). Türkiye’de elektrik enerjisi piyasasında regülasyon uygulamaları (Unpublished doctoral dissertation). Kirıkkale University, Turkey.

Özel, Ç., Özcan Büyüktanır, B. G. and Özel, F. (2013). Elektrik piyasalarında elektrik sağlama amaçlı sözleşmeler [Contract for electricity supply in electricity markets] [Special issue]. Journal of Yaşar University, 8, 2075-2126. Retrieved from https://dergipark.org.tr/en/pub/jyasar/issue/ $19146 / 203211$

Pamir, N. (2017). Enerjinin iktidart. İstanbul: Hayy Kitap.

TMMOB. (2018). Türkiye’nin enerji görünümü 2018 Oda Raporu. Retrieved from https://www.mmo.org.tr/sites/default/files/EnerjiGorunumu2018_1.pdf 
Toledo, P. (2005). Classic realism and the balance of power theory. Glendon Journal of International Studies, 4, 52-63. Retrieved from https://gjis.journals.yorku.ca/index.php/gjis/

Turkey Electricity Transmission Company. (2019). 2019 faaliyet raporu. Retrieved from http://www.sp.gov.tr/upload/xSPRapor/files/29SPg+TEIAS_2019_Faaliyet_Raporu.pdf

Türkoğlu, G. (2005, Aralık). Ülkemiz elektrik sektöründe özelleştirme uygulaması üzerine düşünceler. Paper presented at the TMMOB Türkiye V. Enerji Sempozyumu. Ankara, Turkey. Retrieved from https://www.emo.org.tr/ekler/e0721b2c6977135_ek.pdf

Ünal, O. (2007). Elektrik piyasası oluşumu. Ankara Barosu Dergisi, 65(4), 83-98. Retrieved from http://www.ankarabarosu.org.tr/e-yayin/dergi/ankara-barosu-dergisi/

War Academies Command. (2006). Türkiye'nin enerji stratejisi ne olmalıdır?. Retrieved from https://www.msu.edu.tr/saren2/files/sempozyum_yayinlari/Turkiyenin_Enerji_Stratejisi_Ne_Olma lidir_Ocak2006.pdf

World Bank. (2015). Turkey's energy transition milestones and challenges. Retrieved from https://documents.worldbank.org/en/publication/documents-reports

Zenginobuz, Ü. (2000). Elektrik sektöründe özelleştirme, rekabet ve regülasyon. Rekabet Kurumu Perşembe Konferanslart. Retrieved from https://www.rekabet.gov.tr/Dosya/persembekonferanslari-yayinlari/perskonfyyn76.pdf 